\title{
Serúlóplasmín og járn. Tengsl við Alzheimersjúkdóm og Parkinsonsjúkdóm
}

Porkell Jóhannesson¹ prófessor úr embætti, Jakob Kristinsson¹ lyfjafræðingur, Guðlaug Pórsdóttir² læknir, Jón Snædal² læknir

\section{ÁGRIP}

Serúlóplasmín (Cp) er svokallaður multi-kopar oxídasi, sem in vivo oxar $\mathrm{Fe}^{2+}$ i $\mathrm{Fe}^{3+}$ og afoxar jafnframt súrefni að fullu í vatn. Cp tryggir að $\mathrm{Fe}^{3+}$ geti bundist transferríni og að magn hvarfgjarns $\mathrm{Fe}^{2+}$ haldist í lágmarki. Í miðtaugakerfinu er pað einkum bundið örmum stirnufrumna með glýkósýlfosfatidýlinósítól-tengi i námunda við æðar. Í Cp eru fjögur virk koparatóm og er festing peirra óskylt ferli myndunar próteinhluta ensímsins. Í Cp-purrð í blóđi (aserúlóplasmínemía) er alger vöntun á Cp og áberandi járnraskanir í miðtaugakerfinu og utan pess. Í Parkinsonsjúkdómi (PD) er bæði Cp-péttni og oxunarvirkni í sermi minnkuð, samfara áberandi járnsöfnun í svartsviðið í miðheila. Cp gæti hamlað uppkomu PD með pví að binda járn í neurómelaníni og varna oxunarskemmdum í orkukornum taugunga í svartsviði. Ríkur erfðapáttur er í PD og breytingar í Cp-genum gætu tengst erfðamynstrinu. Í Alzheimersjúkdómi (AD) er oxunarvirkni Cp minnkuð í sermi, en ekki péttni pess. Breytingar í $\mathrm{Cp}$-genum virðast ekki tengjast $A D$. Við AD eru bæði járnraskanir og vöntun á kopar í heilanum. Koparskortur gæti valdið truflun á myndun virks $\mathrm{Cp}$ auk annarra koparensíma í heila. ÆEtla má að trufluð $\mathrm{Cp}$-virkni, og par með raskaður járnbúskapur, skipti máli við $P D$ og við $A D$ ásamt hugsanlega truflunum á öðrum koparensímum.
${ }^{1}$ Rannsóknastofu i lyfja- og eiturefnafræð̌i Háskóla Íslands, º̈ldrunarlækningadeild Landspítala Landakoti.

Fyrirspurnir: Jón Snædal isnaedal@landspitali.is

Greinin barst: 12 apríl 2012, sampykkt til birtingar

12. sept. 2012.

Engin hagsmunatengs। gefin upp.

\section{Inngangur}

Árið 2003 birtu prír höfundanna (JJ, JK og JS) yfirlitsgrein í Læknablaðinu um rannsóknir á premur oxavarnarensímum (serúlóplasmíni (Cp) í sermi, súperoxíðdismútasa (SOD1) í rauðum blóðkornum og glútatíonperoxídasa (GPX) í blóði) í hrörnunarsjúkdómum í miðtaugakerfi í mönnum og sauðfé. ${ }^{1}$ Í mönnum var leitast við að rannsaka Alzheimersjúkdóm (AD) og Parkinsonsjúkdóm (PD), en auk pess hreyfitaugungahrörnun (amyotrophic lateral sclerosis), Downsheilkenni og Wilsonsjúkdóm og til samanburðar fór fram rannsókn á einhverfu.

Rannsóknir á SOD1 og GPX gáfu ekki einhlítar niðurstöður. Greina mátti hins vegar ákveðin mynstur minnkaðrar Cp-oxídasavirkni og péttni í AD og PD. Petta varð endanlega ljóst pegar fyrir lágu niðurstöðutölur úr tvennum tvenndarrannsóknum (age- and gender-matched studies) á Alzheimersjúklingum annars vegar og tveimur tvenndarrannsóknum á Parkinsonsjúklingum hins vegar. $^{2-5}$ Rannsóknir á sjaldgæfum arfbundnum sjúkdómi, Cp-purrð í blóði (aceruloplasminemia), sýna að $\mathrm{Cp}$ er nauðsynlegt fyrir rétta stýringu á járnbúskap í líkamanum, og bæði við AD og PD eru pekktar járnútfellingar og/eða truflanir á járnbúskap í heila. Á grundvelli pessara rannsókna og annarra nýlegra sem síðar greinir, var pví ályktað að röskun á járnbúskap í heila og minnkuð virkni, með eða án minnkaðrar péttni $\mathrm{Cp}$, dæmt út frá gildum í sermi, gætu verið marktækir pættir í meingerð pessara sjúkdóma.

Leitast er við að gefa stutt yfirlit yfir serúlóplasmín, Cp-purrð og gildi Cp fyrir járnbúskap, röskun á járni í heila við $\mathrm{AD}$ og $\mathrm{PD}$ og Cp-péttni og virkni (oxídasavirkni; oxunarvirkni) í sermi við AD og PD. Í lokaorðum eru settar fram nokkrar fyllri ályktanir og spáð í frekari rannsóknir. Yfirlitið er miðað við árslok 2011.

\section{Serúlóplasmín (Cp): Gerð, verkun og myndun}

Tveir sænskir vísindamenn lýstu pví árin 1947-1948 að peir hefðu einangrað $\alpha$-glóbúlín í plasma, sem við venjulegar aðstæður hefur að geyma um og yfir 90\% af öllum kopar í plasma/sermi og ber bláan lit. Peir gerðu einnig grein fyrir öðru glóbúlíni í plasma, sem inniheldur járn en ekki kopar. Fyrra próteinið nefndu peir serúlóplasmín (ceruloplasmin; $\mathrm{C} p$ ) eftir bláa litnum („hið himinbláa prótein í plasma“), en hið síðara transferrín (Tf) vegna járninnihalds og getu til pess að flytja járn.6,7 Síðari rannsóknir hafa svo sýnt að pessi tvö prótein eru að miklu leyti samtengd að verkunum. Árið 1966 birtust pannig grundvallarrannsóknir sem sýndu, að Cp væri oxídasi og skipti meginmáli fyrir rétta oxun á ferrójárni í ferríjárn, sem binst transferríni. 7,8

Hjá mönnum eru 1046 amínósýrur í einum streng í sameind Cp og sameindapunginn er $132 \mathrm{kDa}$. Gen Cp er staðsett á litningi 3 (3q23-25). Gensvæði Tf og transferrínviðtækja (Tfr) eru par mjög nærri. Petta hefur fætt af sér hugmyndir um að á litningi 3 gæti verið setur fyrir einhvers konar ,járnstýristöð“7,9

Í sameind Cp eru alls 6 koparatóm sem hnituð (coordinated) eru með nokkuð mismunandi hætti við atóm í sameindinni. Fjögur pessara atóma mynda svokölluð virk sæti par sem koparatómin oxast og afoxast á víxl. Sameind Cp fær við petta eiginleika oxídasa. Eitt pessara koparatóma er staksett og gefur efninu bláan lit. Hin prjú koparatómin eru saman í hnapp (tricluster). Blálitaða atómið er talið taka við rafeindum frá áverk- 
unarefninu, sem í fyrstu röð er ferrójárn, og flytur rafeindir yfir á hnappsettu koparatómin. Samtímis oxast ferrójárn í ferríjárn, sem er forsenda fyrir bindingu járns í transferrín. Súrefni afoxast pví næst að fullu í vatn fyrir tilstilli hnappsettu atómanna. Vegna pess hve oxun á járni er ríkjandi í verkun Cp er pað oft nefnt ferroxídasi (sjá mynd 1) og er talið til svokallaðra multi-kopar-oxídasa. Meðal multi-kopar-oxídasa er hephaestín, sem verkar mjög hliðstætt við Cp og skiptir meginmáli við frásog á járni frá meltingarvegi. Pað er einnig í miðtaugakerfinu, en mest í heilaberki og par á meðal í taugungum par sem $\mathrm{Cp}$ er einkum í stirnufrumum (astrocytes) og mest í svartsviðinu (substantia nigra). Sampætting pessara ensíma er óljós, en tilraunir benda til pess að pau hafi samverkandi verkun. ${ }^{10}$ Annar pekktur oxídasi í pessum flokki er askorbínsýruoxídasi. ${ }^{7,9}$

Við súrefnisríkar aðstæður in vivo oxast ferrójárn $\left(\mathrm{Fe}^{2+}\right)$ greiðlega í ferríjárn $\left(\mathrm{Fe}^{3+}\right)$. Pessi sjálfsprottnu efnahvörf eru samt hvorki öll á einn veg né „,hrein“. Ein slík hvörf eru svokölluð Fenton-hvörf: $\mathrm{Fe}^{2+}+\mathrm{H}_{2} \mathrm{O}_{2}=>\mathrm{Fe}^{3+}+\bullet \mathrm{OH}+\mathrm{OH}^{-}$. Í slíkum tilvikum myndast stakeind, hýdroxýlfríhópur $(\bullet \mathrm{OH})$, sem veldur umtalsverðum vefjaskemmdum par nærri sem hún myndast. Rökrétt er að ætla að hætta á Fenton-hvörfum aukist eftir pví sem ferroxídasavirkni Cp er minni. Allar líkur eru pess vegna á pví að megingildi $\mathrm{Cp}$ við oxun á járni sé að tryggja að járnatómin komist sem minnst í samband við oxandi efni í umhverfinu (í dæminu að ofan $\mathrm{H}_{2} \mathrm{O}_{2}$ ). Auk pess að hafa beina ferroxídasavirkni hefur Cp áhrif á stöðugleika ferróportíns (Fpn), sem ber tvígilt járn út um himnur ýmissa frumna (carrier). ${ }^{9}, 10$

Pótt ferrójárn sé án efa aðaláverkunarefni Cp, er vel hugsanlegt að pað geti einnig oxað fleiri efni í líkamanum. Hér má nefna kopar, sem getur hvarfast eins og járn í Fenton-hvörfum. Hverfandi lítið er hins vegar af fríum kopar í líkamanum við venjulegar aðstæður. Mun meiri athygli vekur að $\mathrm{Cp}$ getur sennilega oxað katekólamín (dópamín, noradrenalín) og stuðlað að myndun dópamín-melaníns (neurómelaníns). ${ }^{9}$ Um petta ræðir nánar í kaflanum um PD.

Cp er svokallað bráđafasaprótein (acute phase reactant) og péttni pess og/eða virkni í sermi eykst pví við sýkingar, bólgur og meiðsl, en einnig á meðgöngu, við öldrun og jafnvel vegna lyfja. Í samræmi við petta eru pað svokallaðir frumuhvatar (cytokines), sem ráða mestu um tjáningu á $\mathrm{Cp}$-geninu (á litningi prjú). Cpgenið er ríkulega tjáð í frumum í lifur, en einnig í mörgum öðrum líffærum, meðal annars í miðtaugakerfi. Kopar er ekki ákvarðandi efni við tjáningu á Cp-geninu, en við koparskort er hætt við að oxunarvirkni Cp minnki. ${ }^{711,12}$

Koparatómin eru fest inn í apóserúlóplasmín (próteinhluta sameindarinnar) af sérstöku ensímkerfi (P-týpu ATP-asa; ATP7B) sem staðsett er í útfærslugöngum (seytugöngum) frumna, einkum í lifur en einnig í öðrum frumum. Í lifur ræður ensímkerfi petta einnig útskilnaði á kopar í galli. Gen pessa ensíms er á litningi 13 (13q14,3). Ferð kopars inn í lifrarfrumur (eða aðrar frumur) og festing kopars í apóserúlóplasmím til hins fullmótaða ensíms hólóserúlóplasmíns er flókið ferli. ${ }^{13}$ Af pessu og framansögðu má pví enn fremur álykta að myndun apóserúlóplasmíns annars vegar og festing kopars í pað hins vegar, séu tveir svo aðskildir ferlar að við ákvarðanir á Cp í sermi skuli ætíð ákvarða bæði péttni og oxunarvirkni pess. Hluti af seyttu Cp í sermi (10-20\%) er koparlaust (óvirkt apóserúlóplasmín). ${ }^{7}$ Péttni Cp var í rannsóknum höf-

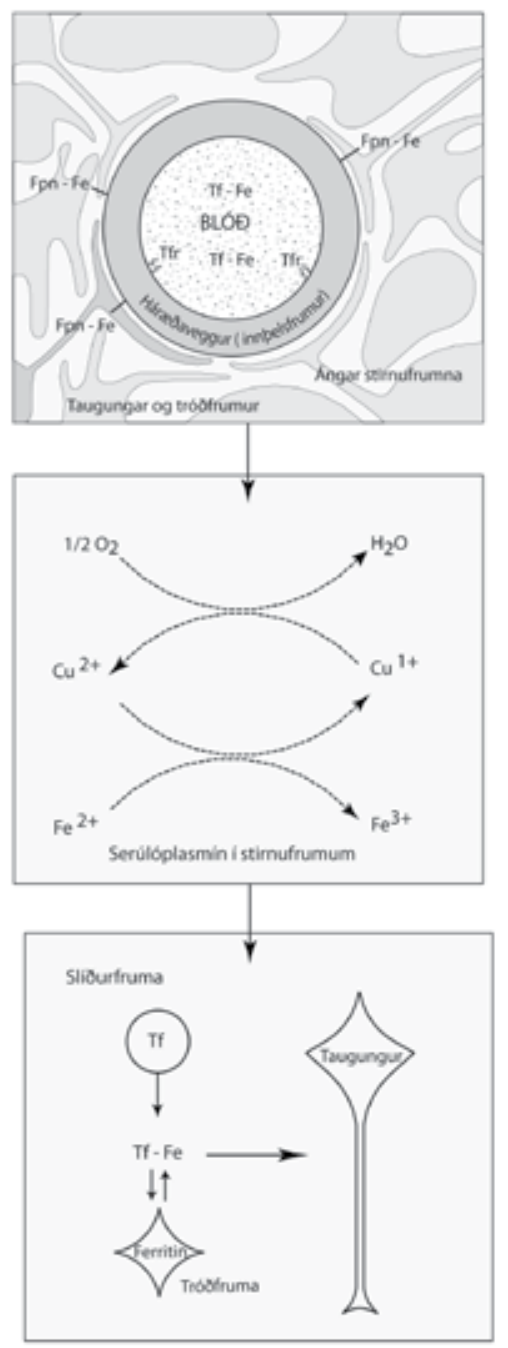

JARNFLEEI INN I HEILANN (IRON INFLUX into CNS)

DXUN JÁRNS

[FERROXIDATION]

FLUTNINGUR JÁRNS TIL TAUGUNGA OG TROEFRUMNA (IRON TRANSPORT to neurons and glia)

Mynd 1. Stílfærð mynd sem sýnir innferð járns í miðtaugakerfið (efst), oxun járns (ferroxidation) af völdum serúlóplasmíns (Cp) ístirnufrumum (astrocytes) (í miðju) og flutning járns til taugunga (neurons) og tróðfrumna (glia) (neðst). - Járnhlaðið (Fe ${ }^{3+}$ ) transferrín (Tf-Fe) í blóði binst við transferrínviðtæki (Tfr) í innpeli háræða í heila. Járnið losnar par frá Tf, er afoxað ( $\left.\mathrm{Fe}^{2+}\right)$ og binst við himnuprótein ( $\left.F p n-F e\right)$, sem ber tvígilt járn y fir himnu frumna. C $p$ fest við anga stirnufrumna (astrocytal end feet) stöðustillir $\mathrm{Fe}^{2+}$ á Fpn og oxar pað í $\mathrm{Fe}^{3+}$, sem bundið Tfflyst til taugunga og í ferritínbirgðir í tróðfrumum.

unda ákvörðuð með mótefnamælingu, sem af hálfu framleiðanda er talin sérhæf.

Cp-sérvirkni er reiknuð stærð yfir oxunarvirkni Cp í hlutfalli við massa og er vísbending um gæði ensímsins. Í sermi 112 einstaklinga af báðum kynjum í viðmiðunarhópum við rannsóknir höfunda2, 3, 5 fór sérvirkni Cp hækkandi með aldri. Hækkandi aldur gæti pví hjá venjulegu fólki leitt til aukinnar festingar á kopar í Cp og aukinnar virkni (mynd 2).

Wilsonsjúkdómur er víkjandi arfbundinn sjúkdómur par sem breytingar eru á áđurnefndu geni á litningi 13. Mjög margar breytingar eru pekktar í pessu geni, sem allar leiða til Wilsonsjúkdóms. Par á meðal er ein genbreyting sem telst vera séríslensk (7-bp deletion in exon 7). ${ }^{14}$ Í Wilsonsjúkdómi er útskilnaður á kopar minnkaður með eftirfarandi útfellingum á kopar í vefjum, meðal annars í miðtaugakerfi. Péttni Cp í sermi er einnig verulega minnkuð, en nokkuð Cp myndast utan lifrar. ${ }^{14}$ 


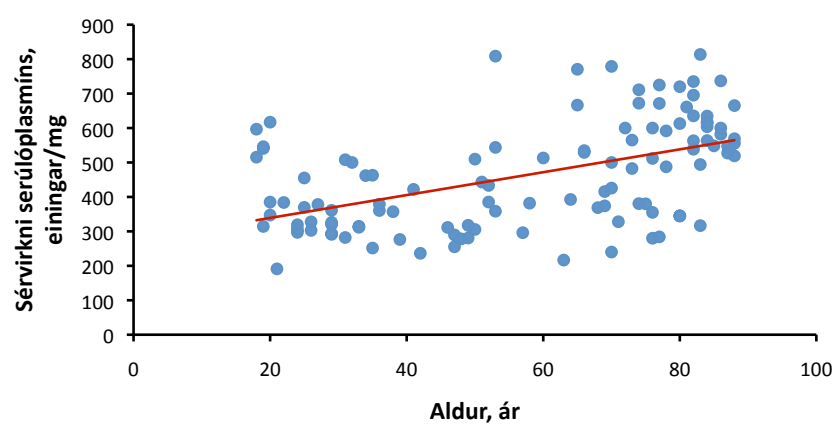

Mynd 2. Sérvirkni serúlóplasmíns (Cp-specific activity) eftir aldri í sermi 112 heilbrigðra einstaklinga (konur 51, karlar 61). Aðhvarfslínan sýnir að sérvirknin eykst marktækt með aldri (línuleg aðhvarfsgreining: $P<0,001$ ).

Cp kemst ekki úr blóði og inn í miðtaugakerfið. Cp í heila er pví myndað par og er seytt í einhverjum mæli frá pekjufrumum í heilahvelum og æðabeðum (plexus choroideus) í heilahvelunum. Mest af Cp í heila myndast í stirnufrumum (astrocytes), en pað eru stærstu tróðfrumurnar í heilanum ( $g$ lia). Pessar frumur hafa marga arma sem liggja víða um taugavefinn. Í mynd 1 er stílfært sýnt hvernig armarnir tengjast pekjufrumum (í háræðum í heila). Cp, sem myndast í stirnufrumunum, er bundið við yfirborð peirra (við enda armanna) með glýkósýlfosfatídýlinósítól-tengi, GPI-tengi. Cp-GPI virðist vera sömu gerðar og seytt Cp. ${ }^{10,15,16}$

\section{Cp-purro í blódi (aceruloplasminemia) og gildi Cp fyrir járnbúskap}

Árið 1987 greindu japanskir vísindamenn frá athyglisverðri sjúkdómsmynd í 52 ára gamalli japanskri konu sem hafði einkenni frá miðtaugakerfi (frá djúphnoðum; basal ganglia), sykursýki og hrörnunarbreytingar í nethimnu augna, samfara útfellingum á járni - og algera vöntun á Cp í sermi. Erfðafræðileg greining á pessum sjúklingi, og litlu síðar víðar um heim á sjúklingum með sams konar einkenni, leiddu í ljós að orsökin myndi vera arfbundnar breytingar (loss of function mutations) í Cp-geninu. Pessi sjúkdómur fékk pví heitið aceruloplasminemia, sem hér er nefnt Cp-purrð í blóði. ${ }^{8} 16$ Sjúkdómurinn er víkjandi arfbundinn sjúkdómur sem hefur verið greindur víða, en pó ekki á Íslandi svo höfundum sé kunnugt. Margháttaðar breytingar á Cp-geninu geta leitt til sjúkdómsins. ${ }^{16}$

Einkenni um Cp-purrð í blóði koma fyrst fram á fullorðinsaldri. Auk sykursýki og sjónskerðingar eru einkenni frá miðtaugakerfi áberandi, ekki aðeins frá djúphnoðum, heldur einnig frá heilaberki með vitrænni skerðingu sem leiðir til heilabilunar. Járn er minnkað í sermi og Tf-mettun er lítil, en ferritín er mjög aukið, sem bendir á minni hreyfanleika járns. Jafnframt pessu er járnmagn aukið í átfrumum í lifur og víðar. Blóðskortur er tiltölulega vægur vegna pess hve járn oxast greiðlega af sjálfu sér (sbr. að framan). Engin merkjanleg truflun er á koparbúskap við Cp-prot í blóði. Er pví talið að Cp skipti ekki máli við stýringu á kopar. Cp-purrð î blóði beindi hins vegar sjónum manna að tengslum $\mathrm{Cp}$ og járns î líkamanum. $7,16-18$

Búið hefur verið til „„ýramódel“ af Cp-purrð íblóði. Eru pað svokallaðar Cp-núllmýs eða $\mathrm{Cp}^{-/-}$mýs par sem Cp-genið á litningi prjú hefur verið fjarlægt. Tilraunir með slíkar mýs sýna að járn safnast í líkamsvefi peirra og er afleiðing af stöðnun járns í frumum sem greiðlega eiga að gefa pað frá sér. Frásog járns frá meltingarvegi er hins vegar óbreytt í pessum músum. ${ }^{18}$ Enn greinilegar má sýna fram á pennan galla pegar gerðar eru tilraunir með einangraðar stirnufrumur úr $\mathrm{Cp}^{-1-}$ músum: Járn losnar margfalt seinna (eða ekki) úr stirnufrumum frá pessum músum en úr stirnufrumum frá venjulegum músum $\left(\mathrm{Cp}^{+/+} \text {músum) }\right)^{18,19}$ Samstaða er um að mjög lítið $\mathrm{Cp}$ purfi að vera til staðar til pess að hringrás járns haldist eðlileg. Petta virðist vera skýringin á pví að greinilegar truflanir á járnbúskap sjást ekki í Wilsonsjúkdómi.

Ferróportín (Fpn) er eins og áður er nefnt í himnu ýmissa frumna. Pað ber tvígilt járn gegnum himnur og út úr frumunum (iron efflux). Ferróportín er prótein sem að verulegu leyti er undir stjórn hormóns (hepsídins) er myndast í lifur, svo og járns í lifrinni. Cp kemur hér einnig við sögu. Ef Cp skortir er hætta á að Fpn innfrumist (endocytosis) og brotni sundur í innanfrumuhömum (lysosomes) pannig að járn verði eftir í frumunum. ${ }^{19,}{ }^{20}$ Vísbendingar eru um að $\mathrm{Cp}$ hamli niðurbroti á Fpn, sérstaklega í miðtaugakerfinu. Ef petta er rétt er stýring $\mathrm{Cp}$ á járnbúskap í miðtaugakerfinu nákvæmari en í öðrum líffærum. ${ }^{20}$

Í megindráttum flytur transferrín (eftir tengingu við transferrínviðtæki, Tfr) prígilt járn úr blóðinu yfir í pekjufrumur í veggjum háræða í miðtaugakerfinu. Par rofnar tengið milli járns og transferríns og járn afoxast í ferrójárn. Ferróportín ber ferrójárn út yfir himnu pekjufrumnanna. Í námunda við himnu pekjufrumnanna eru armar stirnufrumna með Cp-GPI bundið við enda armanna. Cp-GPI stýrir pví næst færslu á $\mathrm{Fe}^{2+}$ úr ferróportíni og oxar pað um leið í $\mathrm{Fe}^{3+}$, sem binst transferríni og flyst pannig um millifrumurýmið í heila til taugunga eða annarra frumna er hafa Tfr (mynd 1). Talið er og að járn komist úr blóðinu inn í miðtaugakerfið óháð transferríni. ${ }^{19,21}$

Ferritín er stórt holulaga prótein gert úr tveimur mismunandi hlutum, H (heavy) og L (light). Járn í ferritíni má skoða sem óhvarfgjarnt en hreyfanlegt birgðajárn. L-hlutinn sér um að binda járn en H-hlutinn hefur ferroxídasavirkni og stuðlar að pví að losa járn úr sameindinni. Ferritín er mest í tróðfrumum, en er einnig í taugafrumum (mynd 1). ${ }^{21}$

\section{Röskun á járni í heila og Cp í sermi við Parkinsonsjúkdóm}

Járni í miðtaugakerfinu er misskipt eftir tegundum frumna og svæðum. Slíðurfrumur tauga (oligodendrocytes) eru járnríkastar allra frumna í miðtaugakerfinu. Par er og talið að Tf myndist að mestu (mynd 1). Ferritín er einnig meira í pessum frumum og tróðlingum (microglia) en í öðrum frumum í miðtaugakerfinu. Petta hefur leitt til kenninga um að járn sé sérstaklega mikilvægt við myndun taugaslíðurs. ${ }^{21,23}$

Meira járn er í utanstrýtusvæði heilans (extrapyramidal regions), pað er í svartsviðinu í miðheila (substantia nigra) og djúphnoðum, en er í öðrum svæðum heilans. Við fæðingu er parna lítið járn en járn vex línulega í svartsviðinu með hækkandi aldri. Ferritín er og meira í pessu svæði en annars staðar í heilanum. Í svartsviðinu er sömuleiðis sérstakur fjölefnungur úr dópamíni (neurómelanín; sjá hér á eftir) sem geymir járn í sjálfum taugungunum og tekur lit af járninu (svartbrúnan lit). Af pví er svo heitið svartsvið dregið..1-23 Ekki er vitað hvers vegna meira járn er í pessum hlutum heilans en öðrum. Nærtækt er samt að ætla að pað endurspegli mikla virkni.

Við Parkinsonsjúkdóm safnast oft sjúklega mikið járn í taugunga í svartsviðinu. Frumurnar missa jafnframt svartbrúna litinn, 
hrörna og deyja, og inni í deyjandi taugungum margra peirra myndast svokallaðar Lewys-agnir (Lewy's bodies). Lewys-agnir eru mýildislíkar próteinútfellingar sem binda járn (sjá einnig næsta kafla). Við Parkinsonsjúkdóm virðist vera skortur á ferritíni. Ef pað er rétt, gæti járn sem hægast safnast óskipulega í taugavefinn (par á meðal Lewys-agnir) og valdið vefjaskemmdum. ${ }^{21,22}$

Rannsókn höfunda á 40 PD-sjúklingum sýndi að Cp-péttni og Cp-oxunarvirkni í sermi var marktækt minni í sjúklingahópnum en í viðmiðunarhópnum. ${ }^{2}$ Fimm árum síðar var gerð framhaldsrannsókn á 28 sjúklingum er pá lifðu úr upphaflega hópnum. Niðurstöður urðu hinar sömu. ${ }^{3} \mathrm{Cp}$-sérvirkni (oxunarvirkni miðað við magn) var sömuleiðis marktækt minnkuð í báðum rannsóknum. Bendir pað á minni gæði ensímsins og má best skýra með minni innbyggingu á kopar í Cp í PD sjúklingunum. ${ }^{2,3}$

Í pessu sambandi ber að nefna að við rannsókn Arnals og félaga ${ }^{24}$ fannst að Cp-péttni í sermi fór hækkandi með versnandi sjúkdómsástandi PD-sjúklinga. Samtímis fór frír kopar (ekki bundinn $\mathrm{Cp}$ ) einnig hækkandi. Ekki var ákvörðuð $\mathrm{Cp}$-virkni. Aukin péttni óbundins kopars í plasma/sermi gæti bent til minni innbyggingar á kopar í Cp og par með minni virkni (sjá einnig næsta kafla).

Í rannsókn Bharucha og félaga ${ }^{25}$ var ákvörðuð Cp-péttni í sermi PD-sjúklinga. Niðurstöður sýndu að Cp-péttnin var marktækt lægri hjá sjúklingunum en var í samanburðarhópnum. Cp-péttnin var enn fremur marktækt lægri í ungum sjúklingum (yngri en 60 ára) en í eldri sjúklingum. Í eldri sjúklingunum, teknum sér, var Cp-péttnin ekki marktækt lægri en í samanburðarhópnum. Höfundar töldu pví að Cp gæti skipt máli fyrir uppkomu PD á yngri árum, en ekki á efri árum. Hvorki í pessari rannsókn né í fyrrnefndum rannsóknum ${ }^{2,3}$ eru vísbendingar um að lyf við PD hafi haft áhrif á niðurstöðutölur.

Tvær mjög nýlegar rannsóknir beinast að sambandinu milli járns í svartsviði og péttni Cp eða oxunarvirkni í sermi. Í fyrri rannsókninni ${ }^{26}$ var járn mælt með segulómun í 7 heilasvæðum hjá PD-sjúklingum. Marktækt aukið járnmagn var einungis að finna í svartsviðinu hjá pessum sjúklingum en pó pví aðeins að $\mathrm{Cp}$ péttni í sermi væri jafnframt lækkuð. Hjá peim sjúklingum par sem járnmagn var ekki aukið í svartsviðinu, var Cp-péttni í sermi ekki heldur minnkuð. Höfundarnir ályktuðu pví að PD gæti að minnsta kosti verið tvenns konar: a) með lágri Cp-péttni í sermi og miklu járni í svartsviði og b) með eðlilegri Cp-péttni í sermi og eðlilega miklu járni í svartsviðinu. Í síðari rannsókninni ${ }^{27}$ var pví lýst að í PD væri neikvæð fylgni milli Cp-oxunarvirkni í sermi og járnmagns í svartsviði. Aukið járn var í svartsviðinu hjá öllum PDsjúklingum og Hoehn- og Yahr-gildi voru nær hin sömu og í fyrri PD-rannsókn höfunda (meðaltöl: 2,45 og 2,40).

Í annarri rannsókn var talið að í meira en 90\% tilvika væri járnmagn í svartsviðinu sjúklega aukið í PD. Hjá mörgum nákomnum ættingjum PD-sjúklinga var sömuleiðis að finna aukið járnmagn í svartsviðinu, enda pótt fæstir peirra greindust með Parkinsonsjúkdóm. Pá er pað enn að í hlutfallslega fáum einstaklingum sem óskyldir voru PD-sjúklingum og heilbrigðir voru, mældist mikið járn í svartsviðinu. ${ }^{28}$ Járnsöfnun ein og sér í svartsviðið er pví samkvæmt pessu ekki nóg til pess að koma Parkinsonsjúkdómi af stað. Með tilliti til pessa er áhugavert að lýst hefur verið $\mathrm{Cp}$ genbreytingum sem tengjast járnsöfnun í svartsviðið og uppkomu PD. ${ }^{29}$ Fyllri rannsókna er augljóslega pörf til pess að kanna hvort og í hve miklum mæli Cp-genbreytingar kunna að tengjast uppkomu PD.

Cp gæti hugsanlega varnað uppkomu Parkinsonsjúkdóms með pví að stuðla að oxun og fjölefningu á dópamíni í dópamínvirkum taugungum í svartsviði í dópamín-melanín, sem áđur er nefnt. ${ }^{9}$ Svipaður fjölefningur myndast í noradrenvirkum taugungum í blásviðinu í heilastofni (locus coeruleus). Samheiti á pessum fjölefnungum er neurómelanín og peir binda járn. Með pví að binda járn getur neurómelanín komið í veg fyrir Fenton-hvörf og hamlað um leið myndun vefjaskemmandi dópamínkínóna. Við hrörnun og dauða taugunga í svartsviðinu losnar neurómelanín, sem tróðlingar sundra. Losnar pá járn samfara stórauknum líkum á Fenton-hvörfum. ${ }^{30}$

Rótenón er lífrænt efni sem unnið er úr plöntum. Рað var áður notað í garðyrkju. Rótenón fer greiðlega inn í miðtaugakerfið og er eitt allmargra efna með sambærilega verkun sem notuð hafa verið í dýratilraunum (mýs, rottur) til pess að framkalla ástand sem minnir í öllum aðalatriðum á PD. Rótenón er pað pessara efna sem hefur sértækasta verkun á orkukorn dópamínvirkra taugunga. Er verkun pess pannig að mestu bundin við dópamínvirka taugunga í svartsviðinu. ${ }^{31}$

Athyglisvert er hve tilraunadýr eru misnæm fyrir áverkun rótenóns. ${ }^{31,32}$ Ekki er vitað í hverju petta mismunandi næmi er fólgið, en pað er lykilatriði að upplýsa. Ekki er petta síst vegna pess að nýlega hefur verið lýst músatilraun par sem ætla mátti að Cp mótverkaði verkun rótenóns á dýrin. ${ }^{33}$

Samantekt: Minnkuð Cp-péttni og oxunarvirkni í sermi, ásamt auknu járni í dópamínvirkum taugungum í svartsviðinu, fer oftast saman við PD. Röskun á orkumyndun í pessum taugungum gæti verið meginatriði við uppkomu PD og Cp varnar hugsanlega pví ferli.

\section{Röskun á járni í heila og Cp í sermi við Alzheimersjúkdóm}

Alzheimersjúkdómur er algengastur svokallaðra heilabilunarsjúkdóma sem rekja má til rýrnunar og frumudauða í heilaberki. Snemma í sjúkdómnum hrörna taugungar sem eiga upphaf sitt í kjörnum neðanvert á ennisblaði heilans (lobus frontalis), einkum Meynert-kjarnanum (Nucleus Basalis of Meynert). Pessir taugungar hafa asetýlkólín að boðefni og mynda brautir sem liggja til drekans (hippocampus) og drekasvæðisins (hippocampal regions) í gagnaugablaði heilans (lobus temporalis). Bilun í pessum brautum veldur minnistruflunum, sem áberandi eru við AD. Síðar hrörna taugungar í hvirfilblaði heilans (lobus parietalis) og víðar í ennisblaðinu. Eru ýmis sjúkleg einkenni til pessa að rekja., ${ }^{1,34}$

Áberandi í meingerð AD eru svokallaðar heilaskellur (cerebral/neuritic plaques) og taugapráðlingar (neurofibrillary tangles). Heilaskellur og práðlingar pekkjast við aðra sjúkdóma en $\mathrm{AD}$, en eru samt talin sérkennandi kennileiti í meingerð AD. Heilaskellurnar eru utan við taugafrumurnar (taugunga) og eru venjulega í námunda við taugungamót (synapses). Práðlingarnir eru aftur á móti innan frumnanna. Peir hafa meira forspárgildi um ástand og framrás sjúkdómsins en heilaskellurnar. ${ }^{1,22,34}$

Í himnu nær allra frumna í líkamanum er stórt forstigsprótein (precursor protein). Af pví klofna peptíðbútar (einkum utan við frumuhimnuna) fyrir tilstilli priggja sérstakra ensímkerfa (sekretasa). Petta prótein kallast $A P P$, sem er stytting úr ensku: 
amyloid precursor protein. Gildi pess próteins og afurða pess gæti falist í endurnýjun frumna eða hluta peirra og í miðtaugakerfinu sérstaklega að viðhalda taugungamótum. Mest af APP klofnar í auðleyst peptíð sem aldrei falla út í vefi. Lítill hluti APP klofnar hins vegar í vatnsfælin $\beta$-peptíð, sem í AD geta safnast saman og myndað strenglaga útfellingar, mýildi (amyloid). Eru pessi peptíð pví nefnd amýlóiðð $\beta$-peptíð eða stytt $A \beta$. Sú klofningsafurð úr APP sem mesta tilhneigingu hefur til pess að mynda mýildi inniheldur 42 amínósýrur, A $\beta,(1-42)$, og myndar kjarnann í heilaskellunum. ${ }^{1}$ 22,34

Í taugungum er prótein sem nefnist tau. Рað binst við frumupíplurnar (microtubuli) í sköftum (axons) taugunga. •að gerir píplurnar stöðugar pannig að flutningur á boðefnum, forstigum boðefna eða næringarefna helst greiður. Í tau-próteininu eru margar amínósýrur sem geta fosfórast (fosfórýlerast). Í AD eru amínósýrurnar í próteininu af einhverjum sökum offosfóraðar (hyperphosphorylated) og snúa próteinið sundur í flóka sem smám saman mynda práðlinga eins og áður ræðir. Við pað falla píplurnar saman og flutningur um pær truflast eða stöðvast. ${ }^{22,34}$ Skemmdir í taugasköftum eru pví ríkjandi í AD.

Járn safnast (ásamt kopar og sinki sem losna við taugaboð) í heilaskellurnar og $\mathrm{A} \beta$ fellur par ekki út nema málmjónir, ekki síst járn, sé einnig til staðar. Ferríjárn $\left(\mathrm{Fe}^{3+}\right)$ binst jafnframt ofurfosfóruðu tau-próteini í AD. Sú binding virðist sömuleiðis vera undanfari myndunar á taugapráðlingum. Járn virðist pví vera nauðsynlegur liður í myndun beggja peirra tveggja kennileita sem öðru fremur einkenna meingerð AD. Pví má svo við bæta að járn er einnig nauðsynlegt til pess að fella prótein, $\alpha$-sýnnúklein, út í mýildislíka myndun í kjarna Lewys-agna í PD. ${ }^{21-23}$

Snemma á 10. áratug liðinnar aldar voru rannsökuð heilasýni úr nýlátnum AD-sjúklingum. ${ }^{35}$ Í pessum sýnum var transferrín dreift kringum heilaskellur og stirnufrumur í stað pess að vera einkum í slíðurfrumum eins og venjulegt er. Sömu höfundar lýstu pví síðar að transferrín væri í minna magni í heila við $\mathrm{AD}$, en magn járns og ferritíns væri breytilegt. ${ }^{36}$ Í annarri rannsókn ${ }^{37}$ var sömuleiðis unnið með sýni úr heila nýlátinna AD-sjúklinga. Niðurstöður peirrar rannsóknar sýndu að járn sem bundið var í heilaskellunum og práðlingunum væri hvarfgjarnt. Járn binst próteinum á $\mathrm{Fe}^{3+}$ formi, en getur afoxast í $\mathrm{Fe}^{2+}$ samtímis pví sem $\mathrm{H}_{2} \mathrm{O}_{2}$ myndast. Súrvatn $\left(\mathrm{H}_{2} \mathrm{O}_{2}\right)$ sem pannig myndast getur pví næst enduroxað $\mathrm{Fe}^{2+} 1 \mathrm{Fe}^{3+}$ samfara myndun á vefjaskemmandi hýdroxýlfríhópi $(\bullet \mathrm{OH})$. Petta eru einmitt Fenton-hvörf sem fyrr ræðir. Í pessu sambandi er athyglisvert að prátt fyrir verulegar raskanir á járni í heila AD-sjúklinga virðist járn ekki verið aukið í heilanum (samanber lokaorð).

Röskun á járnbúskap með líkum á Fenton-hvörfum má greina snemma á sjúkdómsferlinum eða pegar á forstigum sjúkdómsins, við væga vitræna skerðingu (mild cognitive impairment). Í pessu sambandi er jafnframt athyglisvert að myndun heilaskellna virðist vera samfara minnkandi oxunarskemmdum í heilanum. ${ }^{38,39}$ Myndun heilaskellna gæti pví í raun verið liður í að binda járn sem við sjúklegt ástand í heilanum við AD yrði ekki bundið öðruvísi. Petta er í samræmi við pá staðreynd að skellurnar verða að pví er virðist ekki til án járns, með eða án annarra málmjóna.

Höfundar ákvörðuðu Cp-péttni og oxunarvirkni í sermi ADsjúklinga með fremur vægan sjúkdóm (MMSE-gildi að meðaltali 15,9). Cp-virkni og sérvirkni var marktækt minni en í viðmiðun- arhópnum. Cp-péttnin var hins vegar sú sama í báđum hópum, svo og péttni kopars í plasma. ${ }^{4}$ Sams konar rannsókn var gerð 12 árum síðar á $\mathrm{AD}$-sjúklingum með heldur vægari sjúkdóm en áður (MMSE-gildi að meðaltali 18,0). Niðurstöður urðu á sama veg og í fyrri rannsókninni. ${ }^{5}$ Á grundvelli pessara endurteknu rannsókna er pað mat höfunda að Cp-oxunarvirkni í sermi sé minni í $\mathrm{AD}$, en ekki Cp-péttni. Líkleg skýring á pessum niðurstöðum er pví að í $\mathrm{AD}$ sé truflun á festingu kopars í sameind Cp ríkjandi, en myndun á apóserúlóplasmíni sé óbreytt. Rannsóknir höfunda náðu að vísu ekki til sjúklinga með langt genginn $\mathrm{AD}$.

Í rannsóknum höfunda var eins og áour segir rík áhersla á að ákvarða bæði oxunarvirkni Cp og péttni. Lækkuð Cp-virkni í sermi getur leitt til aukinnar Cp-péttni til uppbótar pverrandi virkni. Í slíkum tilvikum leiðir ákvörðun á Cp-péttni til misvísandi eða villandi upplýsinga ef pess er ekki einnig gætt að ákvarða virkni Cp. Petta gæti pví vel skýrt hvers vegna aukin Cp-péttni í sermi hefur stundum verið talin vera skilmerki um AD. Sama á einnig við um rannsóknir á Cp í PD. ${ }^{40}$

Í rannsókn Arnals ${ }^{24}$ var ákvörðuð Cp-péttni í AD á premur stigum sjúkdómsins (mild, intermediate og severe; MMSE-gildi að meðaltali 22,2, 15,9 og 11,6). Cp-péttni í sermi var marktækt minni í veikasta hópnum en í viðmiðunarhópnum. Marktækur munur var ekki á hinum hópunum. Frír kopar í plasma (ekki bundinn Cp) fór hækkandi með versnandi sjúkdómsástandi og óx í línulegu samhengi við minnkandi MMSE-gildi. Niðurstöður nýlegra rannsókna Brewers og félaga ${ }^{41}$ eru á sömu lund og höfunda. ${ }^{4,}{ }^{5}$ Cp-péttni í sermi var pannig óbreytt í AD, en Cp-virknin marktækt minnkuð. Í pessum rannsóknum var frír kopar enn fremur marktækt aukinn í plasma AD sjúklinganna. Brewer ${ }^{41}$ skýrði petta á pann veg að kopar hefði vantað í Cp (,(it) lacks at least some of its coppers“). Í pessu sambandi ber að hafa í huga að veikustu sjúklingarnir í rannsókn Arnals voru mun veikari (höfðu að meðaltali lægri MMSE-gildi) en sjúklingar í rannsóknum Brewers ${ }^{41}$ eða höfunda. ${ }^{4,5}$ Sá möguleiki er pví greinilega til staðar að við langt genginn Alzheimersjúkdóm sé Cp-péttni í sermi einnig marktækt minnkuð.

Squitti og félagar ${ }^{42,}{ }^{43}$ hafa á síðustu árum haldið pví fram að magn frís kopars í plasma AD-sjúklinga gefi vísbendingu um sjúkdómsferilinn. Höfundum er ekki kunnugt um að Squitti hafi ákvarðað Cp-virkni ásamt Cp-péttni. Af peim sökum er pví erfitt á grundvelli peirra rannsókna að álykta hvort frír kopar í plasma sé óháð stærð breytingum í Cp-virkni. Rannsóknir Brewers ${ }^{41}$ sem að framan greinir benda til pess að samband sé milli pessara tveggja pátta. Aukning á fríum kopar í rannsóknum Squittis gæti pví hafa verið afleiðing af minni Cp-virkni í sermi. Í pessu sambandi er athyglisvert að samkvæmt nýlegri stórgreiningu (meta - analysis) er kopar stórlega minnkaður í heila við AD.44 Öfugt við járn fer kopar að líkindum einkum úr blóðinu og inn í miðtaugakerfið á jónuðu formi ${ }^{45}$ Engin vöntun er á kopar í sermi eða heila-mænuvökva í AD. ${ }^{4,42}$ Pví gæti innferð kopars í miðtaugakerfið verið minnkuð í $\mathrm{AD}$ og pað bitnað á virkni fleiri koparensíma en Cp.

Samantekt: Röskun á járnbúskap í heila við AD markast af oxunarskemmdum af völdum járns, járnsöfnun í heilaskellur og taugapráđlinga og af hugsanlegum járnskorti. Cp-oxunarvirkni í sermi er minnkuð. Hömlun á festingu kopars í Cp, auk skorts á ensímkopar í heila, gæti stuðlað að AD. 


\section{Lokaord}

Við Cp-purrð í blóði er alger vöntun á Cp og ótvíræð merki um járnraskanir í miðtaugakerfinu og utan pess. Í PD er nokkuð gott samhengi milli járnsöfnunar í svartsviðið annars vegar og minnkaðrar Cp-péttni og oxunarvirkni í sermi hins vegar. Breytingar í Cp-geni tengjast einnig að ætla má járnsöfnun í svartsviðið. Járnraskanir eru litlar eða engar utan miðtaugakerfisins við PD² (sjá pó $\left.{ }^{46}\right)$. Ef péttni og virkni Cp er ámóta skert í svartsviði og er í sermi, hljóta sérstakar aðstæður að valda pví að járnraskanir við PD eru nær eingöngu bundnar við miðtaugakerfið.

Minnkuð Cp-virkni gæti ein sér skipt verulegu máli við uppkomu $\mathrm{AD}$, en meðal margháttaðra greindra genbreytinga í síðkomnum Alzheimersjúkdómi (langflest tilfelli AD) eru ekki staðfestar breytingar á Cp-geninu, ${ }^{47}$ rannsóknin tók einnig til íslensks efniviðar). Járn er ekki aukið í heilanum við AD með nokkurri vissu. ${ }^{44}$ Pví er rökrétt að ætla að járnraskanir í heila AD-sjúklinga séu til orðnar vegna pess að járn og járnprótein hafi farið afvega af réttum stöðum í heilanum og við pað valdið peim sjúklegu breytingum sem einkenna meingerð AD. Рá er á pað að líta að koparskortur í heila $\mathrm{AD}$-sjúklinga getur valdið skerðingu á starfi margra koparensíma annarra en serúlóplasmíns. Petta er mikilvægt rannsóknarefni að kanna.

Skyldleikatengsl PD-sjúklinga eru mikil, meðal annars samkvæmt íslenskri rannsókn. ${ }^{48}$ Pví er mikilvægt að kanna hvort og hvernig breytingar á Cp-geni kunna að tengjast pessu erfðamynstri. Enn fremur er nauðsynlegt að kanna hvern pátt aðrir pekktir oxídasar í miðtaugakerfinu, sem að framan eru nefndir, gætu átt í uppkomu AD og PD. Að síðustu skal bent á að með nútímastofnfrumutækni ætti að vera unnt að greina hvort eða að hve miklu leyti truflun í starfi Cp er meðfædd í AD og PD. ${ }^{49}$

Hvað er helst: Truflun í starfi Cp virðist tengjast uppkomu PD og gæti verið liður í víðtækari truflunum á starfi koparensíma í $\mathrm{AD}$.

\section{pakkarord}

Sigurlaugu Sveinbjörnsdóttur taugasjúkdómalækni er pakkað áralangt samstarf. Kristínu Björgu Guðmundsdóttur dýralækni eru pökkuð góð ráð og aðstoð við samningu handrits.

\section{ENGLISH SUMMARY}

\section{Ceruloplasmin (Cp) and iron in connection with Parkinson's disease (PD) and Alzheimer's disease (AD)}

Johannesson $\mathrm{T}^{1}$, Kristinsson $\mathrm{J}^{1}$, Torsdottir $\mathrm{G}^{2}$, Snaedal $\mathrm{J}^{2}$

Ceruloplasmin, a multi-copper oxidase with four active copper atoms, oxidizes $\mathrm{Fe}^{2+}$ to $\mathrm{Fe}^{3+}$ and concomittantly fully reduces oxygen to water. The oxygenation of iron is a requisite for transferrin transport of iron and keeping noxious $\mathrm{Fe}^{2+}$ low. In the central nervous system (CNS) Cp is mostly localized in end feet of astrocytes surrounding capillaries and attached by a glycosylphosphatidylinositol-anchor. In aceruloplasminaemia, a rare recessive hereditary disease, complete loss of $\mathrm{Cp}$ is accompanied by disorders of iron metabolism and lesions in CNS and outside. In PD Cp concentration and oxidative activity in serum are significantly lowered with iron deposits and lesions in substantia nigra and basal ganglia. Changes in $\mathrm{Cp}$-genes might be causative in these disorders. By inducing neuromelanin synthesis $\mathrm{Cp}$ may protect neurons in substantia nigra. In AD Cp activity in serum, but not concentration, is significantly lowered. Changes in $\mathrm{Cp}$-genes have not been verified in AD. Total amounts of iron are not increased in AD brains although iron deposits and cortical lesions are numerous. Total copper is significantly lowered in AD brains. This may result in defective synthesis of $\mathrm{Cp}$ and other copper enzymes. - In conclusion, the defective Cp activity, associated with iron disorders, is seemingly of importance in PD and also in $A D$ with other copper enzyme defects possibly involved. 


\section{Heimildir}

1. Jóhannesson P, Kristinsson J, Snædal J. Hrörnunarsjúkdómar í heila - oxavarnarensím og kopar. Kynning á rannsóknum. Læknablaðið 2003; 89: 659-71.

2. Torsdottir G, Kristinsson J, Sveinbjörnsdottir S, Snaeda J, Johannesson T. Copper, ceruloplasmin, superoxide dismutase and iron parameters in Parkinson's disease. Pharmacol Toxicol 1999; 85: 239-43.

3. Torsdottir G, Sveinbjörnsdottir S, Kristinsson J, Snaedal J, Johannesson T. Ceruloplasmin and superoxide dismutase (SOD1) in Parkinson's disease: A follow-up study. J Neurol Sci 2006; 241: 53-8.

4. Snaedal J, Kristinsson J, Gunnarsdottir S, Olafsdottir A, Baldvinsson M, Johannesson T. Copper, ceruloplasmin and superoxide dismutase in patients with Alzheimer's disease. A case-control study. Dement Geriatr Cogn Disord 1998; 9: 239-42. (Cp-sérvirkni í pessari rannsókn, sem nefnd er í meginmáli, var fyrst reiknuð út síðar.)

5. Torsdottir G, Kristinsson J, Snaedal J, Johannesson T. Ceruloplasmin and iron proteins in the serum of patients with Alzheimer's disease. Dement Geriatr Cogn Disord Extra 2011; 1: 366-71.

6. Holmberg CG, Laurell CB. Investigations in serum copper I. Nature of serum copper and its relation to the ironbinding protein in human serum. Acta Chem Scand 1947; 1: 944-50.

7. Harris ZL, Morita H, Gitlin JD. The biology of human ceruloplasmin. In: Messerschmidt A, ed. Multi-Copper Oxidases (chapter 10). World Scientific, Singapore 1997: 285-305.

8. Harris ZL, Takahashi Y, Miyajima H, Serizawa M, MacGillivray RTA, Gitlin JD. Aceruloplasminemia: Molecular characterization of this disorder of iron metabolism. Proc Natl Acad Sci 1995; 22: 2539-43.

9. Vassiliev V, Harris ZL, Zatta P. Ceruloplasmin in neurodegenerative diseases. Brain Res Rev 2005; 49: 63340.

10. Texel SJ, $\mathrm{Xu} X$, Harris ZL. Ceruloplasmin in neurodegenerative diseases. Biochem Soc Trans 2008; 36 : 1277-81.

11. Barber EF, Cousins RJ. Interleukin-1-stimulated induction of ceruloplasmin synthesis in normal and copper-deficient rats. J Nutr 1988; 118: 375-81.

12. Barber EF, Cousins RJ. Induction of ceruloplasmin synthesis by retinoic acid in rats: Influence of dietary copper and vitamin A status. J Nutr 1987; 117: 1615-22.

13. Roberts EA, Sarkar B. Liver as a key organ in the supply, storage, and excretion of copper. Am J Clin Nutr 2008; 88 ( suppl ): $851 \mathrm{~S}-854 \mathrm{~S}$

14. Torsdottir G, Gudmundsson G, Kristinsson J, Snaedal J, Johannesson T. Ceruloplasmin and superoxide dismutase (SOD1) in heterozygotes for Wilson disease: A case control study. Neuropsychiatr Dis Treat 2009; 5: 55-9.

15. Patel BN, David S. A novel glycosylphosphatidylinositolanchored form of ceruloplasmin is expressed by mammalian astrocytes. J Biol Chem 1997; 272: 20185-90.

16. Hellman NE, Gitlin JD. Ceruloplasmin metabolism and function. Ann Rev Nutr 2002; 22: 439-58.

17. Harris ZL, Klomp LW, Gitlin JD. Aceruloplasminemia: an inherited neurodegenerative disease with impairmen of iron homeostasis. Am J Clin Nutr 1998; 67 (Suppl): 972S-977S.

18. Harris ZL, Durley AP, Man TK, Gitlin JD. Targeted gene disruption reveals an essential role for ceruloplasmin in cellular iron efflux. Proc Natl Acad Sci 1999: 96: 10812-7.
19. Jeong SY, David S. Glycosylphosphatidylinositolanchored ceruloplasmin is required for iron efflux from cells in the central nervous system. J Biol Chem 2003; 278: 27144-8.

20. De Domenico I, Ward DM, di Patti MCB, Jeong SY, David S, Musci G, Kaplan J. Ferroxidase activity is required for the stability of cell surface ferroportin in cells expressing GPI-ceruloplasmin. EMBO J 2007; 26: 2823-31.

21. Zecca L, Youdim MB, Riederer P, Connor JR, Crichton RR. Iron, brain ageing and neurodegenerative disorders. Nat Rev Neurosci 2004; 5: 863-73.

22. Altamura S, Muckenthaler MU. Iron toxicity in diseases of aging: Alzheimer's disease, Parkinson's disease and atherosclerosis. J Alzheimer's Dis 2009; 16: 879-95.

23. Barnham KJ, Masters CL, Bush AI. Neurodegenerative diseases and oxidative stress. Nat Rev Drug Discov 2004; 3: 205-14.

24. Arnal N, Cristalli DO, de Alaniz MJT, Marra CA. Clinical utility of copper, ceruloplasmin, and metallothionein plasma determinations in human neurodegenerative patients and their first-degree relatives. Brain Res 2010; 1319: 118-30.

25. Bharucha KJ, Friedman JK, Vincent AS, Ross ED. Lower serum ceruloplasmin levels correlate with younger age of onset in Parkinson's disease. J Neurol 2008; 255: 1957-62.

26. Jin L, Wang J, Zhao L, Jin H, Fei G, Zhang Y, et al. Decreased serum ceruloplasmin levels characteristically aggravate nigral iron deposition in Parkinson's disease. Brain 2011; 134: 50-8.

27. Martinez-Hernandez R, Montes S, Higuera-Calleja J, Yescas P, Boll MC, Diaz-Ruiz A, et al. Plasma ceruloplasmin ferroxidase activity correlates with the nigral sonographic area in Parkinson's disease patients: A pilot study. Neurochem Res 2011; 36: 2111-5.

28. Berg D, Hochstrasser H, Schweitzer KJ, Riess O. Disturbance of iron metabolism in Parkinson's disease ultrasonography as a biomarker. Neurotox Res 2006; 9: $1-13$

29. Hochstrasser H, Bauer P, Walter U, Behnke S, Spiegel J, Csoti I, et al. Ceruloplasmin gene variations and substantia nigra hyperechogenicity in Parkinson disease. Neurology 2004; 63: 1912-7.

30. Zecca L, Casella L, Albertini A, Bellei C, Zucca FA, Engelen $\mathrm{M}$, et al. Neuromelanin can protect against iron-mediated oxidative damage in system modeling iron overload of brain aging and Parkinson's disease. J Neurochem 2008; 106: $1866-75$

31. Uversky VN. Neurotoxicant-induced animal models of Parkinson's disease: understanding the role of rotenone, maneb and paraquat in neurodegeneration. Cell Tissue Res 2004; 318: 225-41.

32. Inden $M$, Kitamura $Y$, Abe $M$, Tamaki A, Takata $K$, Taniguchi T. Parkinsonian rotenone mouse model: Reevaluation of long-term administration of rotenone in C57BL/6 mice. Biol Pharm Bull 2011; 34: 92-6.

33. Hineno A, Kaneko K, Yoshida K, Ikeda S. Ceruloplasmin protects against rotenone-induced oxidative stress and neurotoxicity. Neurochem Res 2011; 36: 2127-35.

34. Blennow K. Alzheimers sykdom - patofysiologi. Information från Läkemedelsverket 2002; 7/8: 21-34.

35. Connor JR, Menzies SL, St Martin SM, Mufson EJ. A histochemical study of iron, transferrin, and ferritin in Alzheimer's diseased brains. J Neurosci Res 1992; 31: 75-83.
36. Connor JR, Snyder BS, Beard JL, Fine RE, Mufson EJ. Regional distribution of iron and iron-regulatory proteins in the brain in aging and Alzheimer's disease. J Neurosci Res 1992; 31: 327-35.

37. Smith MA, Harris PLK, Sayre LM, Perry G. Iron accumulation in Alzheimer disease is a source of redoxgenerated free radicals. Proc Natl Acad Sci 1997; 94: 9866-

38. Smith MA, Zhu X, Tabaton M, Liu G, McKeel DW, Cohen $\mathrm{ML}$, et al. Increased iron and free radical generation in preclinical Alzheimer disease and mild cognitive impairment. J Alzheimers Dis 2010; 19: 363-72.

39. Nunomura A, Perry G, Aliev G, Hirai K, Takeda A, Balraj EK, et al. Oxidative damage is the earliest event in Alzheimer disease. J Neuropathol Exp Neurol 2001; 60: 759-67.

40. Torsdottir G, Kristinsson J, Snaedal J, Sveinbjörnsdottir S, Gudmundsson G, Hreidarsson S, et al. Case-control studies on ceruloplasmin and superoxide dismutase (SOD1) in neurodegenerative diseases: A short review. J Neurol Sci 2010; 299: 51-4.

41. Brewer GJ, Kanzer SH, Zimmerman EA, Celmins DF, Heckman SM, Dick R. Copper and ceruloplasmin abnormalities in Alzheimer's disease. Am J Alzheimers Dis Other Demen 2010; 25: 490-7.

42. Bucossi S, Ventriglia M, Panetta V, Salustri C, Pasqualetti P, Mariani S, et al. Copper in Alzheimer's disease: A metaanalysis of serum, plasma, and cerebrospinal fluid studies. J Alzheimers Dis 2011; 24: 175-85.

43. Squitti R, Ghidoni R, Scrascia F, Benussi L, Panetta $\mathrm{V}$, Pasqualetti $\mathrm{P}$, et al. Free copper distinguishes mild cognitive impairment subjects from healthy elderly individuals. J Alzheimers Dis 2011; 23: 239-48.

44. Schrag M, Mueller C, Oyoyo U, Smith MA, Kirsch WM. Iron, zinc and copper in the Alzheimer's disease brain: A quantitative meta-analysis. Some insight on the influence of citation bias on scientific opinion. Prog Neurobiol 2011; 94: 296-306.

45. Choi BS, Zheng W. Copper transport to the brain by the blood-brain barrier and blood-CSF barrier. Brain Res 2009; 1248: 14-21.

46. Logroscino G, Marder K, Graziano J, Freyer G, Slavkovich $\mathrm{V}$, Lolacono $\mathrm{N}$, et al. Altered systemic iron metabolism in Parkinson's disease. Neurology 1997; 49: 714-7.

47. Hollingworth P, Harold D, Sims R, Gerrish A, Lambert $\mathrm{JC}$, Carrasquillo MM, et al. Common variants at $A B C A 7$, MS4A6A/ MS4A4E, EPHA1, CD33 and CD2AP are associated with Alzheimer's disease. Nat Genet 2011; 43: 429-36.

48. Sveinbjörnsdottir S, Hicks AA, Jonsson T, Petursson $H$, Gudmundsson G, Frigge, et al. Familial aggregation of Parkinson's disease in Iceland. N Engl J Med 2000; 343: $1765-70$

49. Dimos JT, Rodolfa KT, Niakan KK, Weisenthal LM, Mitsumoto $\mathrm{H}$, Chung $\mathrm{W}$, et al. Induced pluripotent stem cells generated from patients with ALS can be differentiated into motor neurons. Science 2008; 321: 121821. 